\title{
Influence of Olive Maturity and Season on the Quality of Virgin Olive Oils from the Area Assigned to the Protected Designation of Origin of "Aceite de la Alcarria" (Spain)
}

\author{
José E. Pardo ${ }^{1, * \mathbb{D}}$, Adrián Rabadán ${ }^{1} \mathbb{D}$, Mariano Suárez ${ }^{1}$, Jacinto Tello ${ }^{1}$, Diego C. Zied ${ }^{2}(\mathbb{D}$ \\ and Manuel Álvarez-Ortí ${ }^{1}$ (D) \\ 1 Escuela Técnica Superior de Ingenieros Agrónomos y de Montes, Universidad de Castilla-La Mancha, \\ Campus Universitario, s/n, 02071 Albacete, Spain; adrian.rabadan@uclm.es (A.R.); \\ mariano.suarez@uclm.es (M.S.); jtello@agroalimentariasclm.coop (J.T.); manuel.alvarez@uclm.es (M.Á.-O.) \\ 2 Faculdade de Ciências Agrárias e Tecnológicas (FCAT), Universidade Estadual Paulista (UNESP), \\ Câmpus de Dracena, Dracena 17900-000, Brazil; dczied@gmail.com \\ * Correspondence: jose.pgonzalez@uclm.es; Tel.: +34-967-599-200
}

\section{check for} updates

Citation: Pardo, J.E.; Rabadán, A.; Suárez, M.; Tello, J.; Zied, D.C.;

Álvarez-Ortí, M. Influence of Olive Maturity and Season on the Quality of Virgin Olive Oils from the Area Assigned to the Protected Designation of Origin of "Aceite de la Alcarria" (Spain). Agronomy 2021, 11, 1439. https://doi.org/10.3390/ agronomy11071439

Academic Editor: Helder Fraga

Received: 17 June 2021

Accepted: 17 July 2021

Published: 20 July 2021

Publisher's Note: MDPI stays neutral with regard to jurisdictional claims in published maps and institutional affiliations.

Copyright: (c) 2021 by the authors. Licensee MDPI, Basel, Switzerland. This article is an open access article distributed under the terms and conditions of the Creative Commons Attribution (CC BY) license (https:/ / creativecommons.org/licenses/by/ $4.0 /)$.

\begin{abstract}
This work aimed to assess the influence of olive maturity and oil season on the potential quality of monovarietal virgin olive oils from the area assigned to the Protected Designation of Origin of "Aceite de la Alcarria" (Spain), analysing the regulated physicochemical quality and sensory parameters, the stability parameters and composition of fatty acids, sterols and triterpenic dialcohols. To complete the study, we also characterised the coupage olive oils made in the oil mills located in the PDO area (real quality). The main variety grown in La Alcarria is Castellana, whose oils are characterised by a high content of palmitic acid (14.27\% with olives in veraison, $13.81 \%$ with ripe olives), a low content of linoleic acid (5.03\% with olives in veraison, 5.98\% with ripe olives) and a total phenol content higher than the rest of varieties grown in the area (between 350 and $500 \mathrm{mg}$ of caffeic acid $/ \mathrm{kg}$ depending on the season considered), which is reflected in higher oxidative stability values (induction time of $50.65 \mathrm{~h}$ at $100{ }^{\circ} \mathrm{C}$ ). In addition, they have a sterol content below that established by the regulations $(<1000 \mathrm{mg} / \mathrm{kg})$. The olive oils produced using olives in veraison presented a lower level of acidity and peroxide index, more intense fruitiness, an absence of defects in all the samples and higher oxidative stability, compared to those produced using ripe olives, and thus early harvest of the olives is recommended. It was also found that the season affects the physicochemical composition of the oils, although these changes tend to be of little significance, with the characteristics of the variety being maintained, regardless of the harvesting season analysed. The coupage virgin olive oils produced in the mills registered under the PDO of Aceite de la Alcarria, representative of their real quality, showed, as expected, similar values to those observed in the monovarietal virgin olive oils produced using the Castellana variety, which is clearly predominant in the study area. The characterization of oils from local varieties allows one to obtain a greater variability in terms of the sensory notes of extra virgin olive oil.
\end{abstract}

Keywords: Alcarria; olive oil quality; monovarietal extra virgin olive oil; maturation; season

\section{Introduction}

The Aceite de la Alcarria Protected Designation of Origin (PDO) was created in 2008 according to the traditionally produced olive oils, with differentiated characteristics. The area where these oils are produced is located in central Spain, in the Autonomous Community of Castilla-La Mancha. The oils enjoy an exceptional reputation due to perfectly defined growing and production practices. The approximate surface area of the PDO is $6000 \mathrm{~km}^{2}$, being home to almost 4 million olive trees [1].

The main characteristics of the oils from this PDO come from the endemic nature of the olive variety Castellana that is grown in the area. This variety accounts for about $90 \%$ of 
the total olive trees grown [2] and is perfectly adapted to the climatic conditions of the area, which make it strongly linked to the PDO. There are also dispersed varieties (Manzanilla de Centro), located in various areas, but which occupy limited amounts of surface area, and local varieties (Gordera and Martín Galgo), found in only one area (endemic), where they are not generally widespread, but play a key environmental role, as they are highly specialised varieties that are adapted to the area, avoiding erosion and desertification, and helping maintain the balance of ecosystems [3]. The Arbequina, which is one of the main varieties in the Spanish PDOs in Catalonia, has recently been introduced into the Aceite de la Alcarria area. Current market trends have added values to these oils, made in specific geographic origins from olives traditionally grown under non-intensive systems $[4,5]$.

Apart from the variety, the characteristics of virgin olive oil can also vary according to the maturity of the olives when harvested. During the ripening process, a series of metabolic routes occur, which can modify the composition of the oil in the olive, generating changes in the composition of the fatty acids, the total phenol content, their antioxidant capacity, and quality parameters [6-8]. In some olive varieties, these changes lead to an increase in polyunsaturated fatty acids (linoleic and linolenic acid), and the consequent decrease in saturated (palmitic and stearic acid) and monounsaturated fatty acids (oleic acid) [8]. The olive ripening may also influence the presence of phenols, which are supposed to lower the incidence of coronary heart diseases and contribute to the flavour of virgin olive oil [9]. Bitter and pungent, which are considered positive attributes in the oils, are elicited by two separate sensory pathways related to the presence of phenolic compounds in the extra virgin olive oils. Certain compounds such as oleuropein and apigenin are perceived as bitter, while the oleocanthal, consisting of an $\alpha \beta$-unsaturated dialdehyde phenolic compound, is perceived as pungent [10]. Thus, olive ripening may affect the sensory properties of the oils, since maturation may reduce the levels of phenolic compounds in the oil.

The agri-environmental conditions and the amount of water received by the olives are factors that can affect the physicochemical composition and sensory characteristics of the olive oil [11-13], which is why it is of interest to study the impact of season on any crop or product.

Studies characterizing virgin olive oils from a particular olive area differentiate between potential and real quality [14-17]. To reach the potential quality of olive oils, the raw material must be selected according to the optimum ripening stage. In addition, it must be free of pests and disease, avoid large storage times and process the oils under optimum conditions, especially avoiding high temperatures and with a rapid separation of residues. On the other hand, the real quality refers to that found in olive oils sampled directly from the storage tanks at the olive oil mills, which leads to evaluating the quality of the oil that reaches consumers.

The main objective of this work was to evaluate the impact of olive maturity and season on the potential quality of monovarietal virgin olive oils elaborated in the area assigned to the PDO Aceite de la Alcarria (Spain), analysing the regulated physicochemical quality parameters (acidity level, peroxide index and extinction coefficients K232, K270) and sensory parameters (fruitiness, bitterness, pungency and the Panel Test classification), stability parameters (total phenol content, tocopherol content and oxidative stability) and the fatty acid, sterol and triterpenic dialcohol composition. In addition, the coupage virgin olive oils produced in the olive mills registered under the PDO were also characterised, which represent their real quality.

\section{Materials and Methods}

\subsection{Plant Material}

The Alcarria region is located in central Spain. It is an area with an altitude of between 700 and $900 \mathrm{~m}$, characterised by having a continental Mediterranean climate with an average annual rainfall of around $383 \mathrm{~mm}$. The continental character of the area is reflected in a high variation in temperatures, both daily and seasonal, which can reach extreme 
values of $-9.9^{\circ} \mathrm{C}$ in winter and $39.7^{\circ} \mathrm{C}$ in summer, with an average annual temperature of $12{ }^{\circ} \mathrm{C}$. In this area, four consecutive olive crop seasons were studied: $2015 / 2016,2016 / 2017$, $2017 / 2018$ and 2018/2019.

A total of 27 plots were selected, which were maintained over the seasons under study. The number of samples were selected according to the abundance of the different varieties grown in the area as follows: Arbequina $=3$; Castellana $=15$; Gordera $=3$; Manzanilla $=3$; Martin Galgo $=3$. For each variety, the plots were distributed throughout the study area, although with a higher number of selected plots where the variety was found to have a higher incidence. Within each plot, 6 olive trees were selected and marked. The previously selected trees were numbered using a special spray and a coloured tag.

The olives were collected at two specific times, beginning in both cases with the earliest varieties. The first collection was done at the beginning of the season, when the olives were in veraison, corresponding to a maturity index (MI) of between 0 and 2.5, which was around the first half of November of the four seasons evaluated: 2015, 2016, 2017 and 2018. The second collection was done in the middle to end of the season around the second half of December, with an MI of between 3.5 and 7 [18]. The total number of samples analysed was 216 ( 27 plots $\times 2$ collections/olive crop season $\times 4$ seasons).

Within each plot, $20 \mathrm{~kg}$ of healthy olives were collected manually from the selected olive trees and put into net sacks. The labelled samples were swiftly taken to the extraction plant to be processed.

\subsection{Olive Oil Extraction}

The olive oil was extracted using a 2-phase extractor, Oliomio TF-30 (Toscana Enológica Mori, Tavarnelle Val di Pesa, FI, Italy), comprising a hammer mill, a thermo-beater and a horizontal centrifuge. Approximately 2 litres of olive oil were extracted from each olive sample. The extraction was conducted under the best production conditions, without storing olives and with a malaxation time of $45 \mathrm{~min}$ at room temperature $\left(24^{\circ} \mathrm{C}\right)$.

The extracted oils were decanted into $250 \mathrm{~mL}$ glass bottles, topaz in colour and with no headspace, being refrigerated until the analysis was conducted.

\subsection{Sampling of Olive Oil Produced in the Mills Registered under the Aceite de la Alcarria PDO}

Three oil mills registered under the PDO at that time (Aceites Delgado, SL, SAT Alcarria Baja and Sociedad Cooperativa Alta Alcarria) were selected.

The virgin olive oil samples (3 litres) were collected directly from the storage tanks at the mills discarding the first portion to eliminate the oil that is in direct contact with the sampler faucet. The samples were taken after the harvesting season (second half of January 2016, 2017, 2018 and 2019). We collected 16 samples for each season, depending on production capacity (4 at Aceites Delgado, S.L., 4 at SAT Alcarria Baja and 8 at Sociedad Cooperativa Alta Alcarria). The total number of samples was 64 (16 samples/season $\times 4$ seasons).

None of the samples collected could be considered monovarietal, as the varieties are not separated on reception. The Castellana variety was, however, predominant in all samples.

\subsection{Oil Analysis}

- $\quad$ Regulated physicochemical quality parameters

The regulated physicochemical quality parameters (free acidity, peroxide index and UV absorption-K232 and K270) were determined following the analytical methods described by Regulation EEC/2568/91 of the Commission of the European Union [19].

- $\quad$ Regulated sensory quality parameters

The regulated sensory quality parameters (median of defects, median fruity value and panel test classification) were determined by selected and trained panellists from the Laboratorio Agroalimentario de Córdoba (Córdoba, Spain), following the method described in Regulation EEC/796/2002 [20]. To evaluate sensory quality, the intensities 
of positive (fruity, bitter and pungent) and negative (fusty, winey, musty, muddy, rancid, metallic and other) attributes were considered for each oil sample.

The descriptive sensory analysis of the oils made from the 5 olive varieties cultivated in the study area, using both ripe olives and olives in veraison, was performed at the Instituto de la Grasa-CSIC—(Seville, Spain).

\section{- $\quad$ Stability parameters}

The stability parameters (total phenol content, tocopherol content and oxidative stability expressed as induction time in hours at $100^{\circ} \mathrm{C}$ ) were analysed using different methodologies.

Total phenols were extracted with a water/methanol mixture $(60: 40 v / v)$ and a subsequent reaction with the Folin-Ciocalteu reagent on an aliquot of the phenolic extract obtained and a spectrophotometric reading of the absorbance of the bluish complexes formed. Values were given as mg of caffeic acid per kg of oil [21].

The tocopherols were evaluated using the AOCS Ce 8-89 method [22].

Oxidative stability was measured using the Rancimat method [23] and was expressed as the oxidation induction time (hours), measured at $100{ }^{\circ} \mathrm{C}$ under an airflow of $10 \mathrm{~L} / \mathrm{h}$ with the Rancimat 743 (Metrohm Co., Basel, Suiza).

- Fatty acid composition

Fatty acid composition, expressed as the percentage (\%) of methyl-esters, was determined according to Regulation EEC 2568/91 and its amendment EEC 1429/92 [24]. Briefly, fatty acid methyl esters (FAME) were obtained by cold transmethylation and analysed by gas chromatography using a CPSil 88 fused silica capillary column $(50 \mathrm{~m} \times 0.25 \mathrm{~mm}$ i.d.), with helium as the carrier gas $(120 \mathrm{KPa})$. The temperature was increased at ate of $5{ }^{\circ} \mathrm{C} / \mathrm{min}$ from $140{ }^{\circ} \mathrm{C}$ to $220{ }^{\circ} \mathrm{C}$ and then maintained for $15 \mathrm{~min}$. The temperature of the injector and detector was 250 and $270^{\circ} \mathrm{C}$ respectively. Each FAME was identified by comparison with a standard mixture (FAME 37, Supelco, Bellefonte, PA, USA) [25].

- Sterol and triterpenic dialcohol composition

Sterols and triterpenic dialcohols, expressed as a percentage (\%), were determined following the procedure described in Regulation EEC 2568/91, corresponding to protocol AOCS Ch 6-91. The apparent $\beta$-sitosterol was calculated as the sum of $\beta$-sitosterol, $\Delta 5,23$-stigmastadienol, cholesterol, sitostanol and $\Delta 5,24$-stigmastadienol.

\subsection{Statistical Analysis}

The significant differences were determined using an analysis of variance. A Duncan test was applied with a 95\% significance level $(p<0.5)$, using SPSS 19.0 for Windows (IBM, Armonk, NY, USA).

\section{Results and Discussion}

3.1. Characterization of Monovarietal Virgin Olive Oils from Aceite de la Alcarria PDO According to Olive Maturity

\subsubsection{Regulated Physicochemical Quality Parameters}

The regulated physicochemical quality parameters are those defined in national and international regulations and determine possible defects in the oils or defects that might subsequently appear [26].

The maturity of olives can affect the regulated physicochemical quality parameters as ripe olives are more sensitive to mechanical damage and pathogen infections, as well as being prone to increase enzymatic activity, which can generate higher levels of free acidity [27].

More mature olives may also deteriorate or undergo fermentation during storage, which can generate defects in the oils produced. In the case of virgin olive oils produced with olives of the varieties grown in the Aceite de la Alcarria PDO, the differences in the parameters of acidity, peroxide index and ultraviolet absorption (K232, K270) show little variation depending on olive maturity (Table 1 ). 
Table 1. Regulated physicochemical parameters for the virgin olive oils produced with the variety of olives grown in the Aceite de la Alcarria PDO (veraison and ripe). The data show the mean value and standard deviation of the oils across the four consecutive olive crop seasons under study.

\begin{tabular}{|c|c|c|c|c|c|}
\hline Variety & Maturity & $\begin{array}{c}\text { Acidity } \\
(\%)\end{array}$ & $\begin{array}{l}\text { Peroxide Index } \\
\left(\mathrm{mEqO}_{2} / \mathrm{kg}\right)\end{array}$ & $K_{232}$ & $K_{270}$ \\
\hline \multirow{2}{*}{ Arbequina } & Veraison & $0.1 \pm 0.01$ & $4.4 \pm 1.4$ & $1.54 \pm 0.09^{a}$ & $0.09 \pm 0.01$ \\
\hline & Ripe & $0.1 \pm 0.02$ & $4.3 \pm 0.7$ & $1.46 \pm 0.07^{b}$ & $0.08 \pm 0.01$ \\
\hline \multirow{2}{*}{ Castellana } & Veraison & $0.1 \pm 0.03$ & $5.0 \pm 1.2$ & $1.70 \pm 0.11^{\mathrm{a}}$ & $0.13 \pm 0.02$ \\
\hline & Ripe & $0.1 \pm 0.05$ & $5.2 \pm 1.4$ & $1.56 \pm 0.10^{b}$ & $0.10 \pm 0.02$ \\
\hline \multirow{2}{*}{ Gordera } & Veraison & $0.1 \pm 0.05^{b}$ & $5.4 \pm 1.3$ & $1.64 \pm 0.17^{a}$ & $0.12 \pm 007$ \\
\hline & Ripe & $0.3 \pm 0.08^{a}$ & $5.4 \pm 1.5$ & $1.43 \pm 0.09^{b}$ & $0.09 \pm 0.02$ \\
\hline \multirow{2}{*}{ Manzanilla } & Veraison & $0.1 \pm 0.02$ & $5.4 \pm 1.2$ & $1.63 \pm 0.13^{b}$ & $0.14 \pm 0.02$ \\
\hline & Ripe & $0.2 \pm 0.03$ & $6.3 \pm 2.8$ & $1.79 \pm 0.27^{\mathrm{a}}$ & $0.14 \pm 0.01$ \\
\hline Martín & Veraison & $0.2 \pm 0.04^{b}$ & $5.6 \pm 0.6^{b}$ & $1.41 \pm 0.16^{b}$ & $0.13 \pm 0.06$ \\
\hline Galgo & Ripe & $0.3 \pm 0.10^{\mathrm{a}}$ & $8.6 \pm 6.3^{\mathrm{a}}$ & $1.58 \pm 0.29^{a}$ & $0.17 \pm 0.16$ \\
\hline
\end{tabular}

Different letters within each variety indicate significant differences between maturity stages (Duncan test, $p<0.05)$.

In the Arbequina, Castellana and Manzanilla variety, small increases in acidity are observed in the oils produced with mature olives, although these are not statistically significant. However, in the Gordera and Martin Galgo varieties, these differences were greater, highlighting the importance of earlier harvesting to obtain optimum quality oils.

The peroxide index values, which indicate the initial oxidation state of the oil, show a similar pattern to that of acidity. In these cases, the differences are especially significant in the Martin Galgo variety, where the oils made with the mature olives present the highest values of all the oils analysed (Table 1). Higher values on the peroxide index may be the result of fermentation reactions in the olives after harvesting.

The spectrophotometric values, K232 and K270, which are typically another measure of olive oil quality, and which measure conjugated dienes and trienes and their secondary oxidation products, do not tend to be clearly associated with olive maturity $[8,27]$. Previous studies have reported a decrease in K232 in oils according to the greater maturity of the olives, as we observed in the Arbequina, Castellana and Gordera varieties. However, the opposite trend is found for the Manzanilla and Martín Galgo varieties. No differences are found for K270 in any of the cases (Table 1).

In any event, the values obtained on all the parameters evaluated are well below the limits established under current legislation (acidity $\leq 0.8 \%$; peroxide index $\leq 20$ meq $\mathrm{O}_{2} / \mathrm{kg}$; $\mathrm{K} 232 \leq 2.50 ; \mathrm{K} 270 \leq 0.22)$ [28]. Hence, all the virgin olive oils analysed, both those produced with olives in veraison and those with mature olives would be classified as extra virgin olive oil.

\subsubsection{Regulated Sensory Quality Parameters}

Table 2 shows the results for the positive sensory attributes evaluated and the panel test classification of the monovarietal oils produced using both mature olives and olives in veraison grown in the Aceite de la Alcarria PDO. 
Table 2. Positive sensory attributes and Panel Test classification for the monovarietal oils produced with the variety of olives grown in the Aceite de la Alcarria PDO (veraison and ripe). The values show the means and standard deviations for the samples collected across the four consecutive olive crop seasons under study.

\begin{tabular}{|c|c|c|c|c|}
\hline & $\begin{array}{l}\text { Fruity } \\
(0-10)\end{array}$ & $\begin{array}{c}\text { Bitter }>5 \\
(\%)\end{array}$ & $\begin{array}{c}\text { Pungent }>5 \\
(\%)\end{array}$ & $\begin{array}{l}\text { Classification } \\
\text { Panel Test (\%) }\end{array}$ \\
\hline $\begin{array}{l}\text { Arbequina } \\
\text { (veraison) }\end{array}$ & $4.4 \pm 0.2^{\mathrm{a}}$ & 0 & 0 & EVOO (100) \\
\hline $\begin{array}{l}\text { Arbequina } \\
\text { (ripe) }\end{array}$ & $4.8 \pm 0.3^{\mathrm{a}}$ & 0 & 0 & EVOO (100) \\
\hline $\begin{array}{l}\text { Castellana } \\
\text { (veraison) }\end{array}$ & $4.4 \pm 0.2^{\mathrm{a}}$ & 13.4 & 80 & EVOO (100) \\
\hline $\begin{array}{l}\text { Castellana } \\
\text { (ripe) }\end{array}$ & $3.6 \pm 0.4^{b}$ & 0 & 80 & $\begin{array}{c}\text { EVOO (91.7)/VOO } \\
(8.3)\end{array}$ \\
\hline $\begin{array}{l}\text { Gordera } \\
\text { (veraison) }\end{array}$ & $4.5 \pm 0.5^{\mathrm{a}}$ & 0 & 0 & EVOO (100) \\
\hline $\begin{array}{l}\text { Gordera } \\
\text { (ripe) }\end{array}$ & $3.9 \pm 0.3^{b}$ & 0 & 0 & EVOO (100) \\
\hline $\begin{array}{l}\text { Manzanilla } \\
\text { (veraison) }\end{array}$ & $4.9 \pm 0.4^{\mathrm{a}}$ & 0 & 100 & EVOO (100) \\
\hline $\begin{array}{l}\text { Manzanilla } \\
\text { (ripe) }\end{array}$ & $3.9 \pm 0.3^{b}$ & 0 & 100 & EVOO (100) \\
\hline $\begin{array}{l}\text { Martín Galgo } \\
\text { (veraison) }\end{array}$ & $3.6 \pm 0.3^{b}$ & 0 & 0 & EVOO (100) \\
\hline $\begin{array}{l}\text { Martín Galgo } \\
\text { (ripe) }\end{array}$ & $3.7 \pm 0.2^{b}$ & 0 & 0 & EVOO (100) \\
\hline
\end{tabular}

Different letters in the same column indicate significant differences $(p<0.05)$. EVOO: Extra Virgin Olive Oil; VOO: Virgin Olive Oil.

Regardless of the season considered, all the virgin olive oil samples made from olives harvested in veraison were classified as "extra virgin" according to Regulation EC /640/2008 [28], since the median of defects was 0 and the median of the fruity attribute was above 0 .

As regards the samples of virgin olive oil produced using mature Castellana olives, 91.7\% were classified as "extra virgin", while the remaining $8.3 \%$ were classified as "virgin", as the median of defects was above 0 and below or equal to 3.5, and the median of the fruity attribute was above 0 . The defect detected was that of "winey", which typically appears in overripe olives, due to fermentation processes beginning [17,29]. This is surprising given that the raw material was in perfect sanitary conditions and the production process was optimal. This only occurred in the 2015/16 season, which led us to recommend early harvesting of this variety to producers in the Aceite de la Alcarria PDO.

Nonetheless, in the following seasons, all the samples were classified as "extra virgin", likely because although the olives were harvested on the same dates, the olives were less ripe due to the greater annual rainfall $(2015=183.12 \mathrm{~mm} ; 2016=444.11 \mathrm{~mm}$; $2017=266.61 \mathrm{~mm} ; 2018=599.17 \mathrm{~mm}$ ), as the mean annual temperature was similar across all the seasons $\left(2015=12.22{ }^{\circ} \mathrm{C} ; 2016=11.98{ }^{\circ} \mathrm{C} ; 2017=11.90{ }^{\circ} \mathrm{C} ; 2018=11.36{ }^{\circ} \mathrm{C}\right)[30]$.

Fruitiness decreased with the maturity stage, although this decline was only significant in the cases of the Castellana, Gordera and Manzanilla varieties. Ripening is typically associated with a decrease in C5 volatiles, which appears to be the cause of the decrease in green odour notes [31].

With regard to the bitter attribute, only $13.4 \%$ of the olive oil samples of the Castellana variety, whose olives had been collected in veraison, presented values above 5 . The more mature olives are, the less bitter are the oils they produce.

The Castellana variety was also characterised by presenting high levels, above 5, of the pungent attribute, in $80 \%$ of oils made with both mature and veraison olives. This percentage was only exceeded by the Manzanilla variety, as all the samples of olive oil 
presented high levels of this attribute. It can be understood, therefore, that high values of pungency may be an intrinsic characteristic of the Manzanilla and Castellana varieties.

\subsubsection{Descriptive Sensory Analysis of the Monovarietal Virgin Olive Oils}

We elaborated a descriptive sensory profile of the monovarietal olive oils produced with olives of the varieties grown in the Aceite de la Alcarria PDO, at two different points in the ripening of the fruits, veraison and maturity. The results were the following:

- Arbequina (veraison): Medium fruity oil with green ripe olives, notes of banana, apple and fennel, with floral and vanilla aromas. In the mouth, it is first sweet, evolving to banana and red fruits. Slightly bitter with a medium pungency, the final taste is of nuts, such as pistachio.

- Arbequina (ripe): Medium fruity with mature olives. Notes of banana and ripe pear, floral aromas and hints of fennel, vanilla and cinnamon. In the mouth, it is first sweet, evolving to dried fruits and ripe fruit: the bitterness is almost imperceptible and the piquancy is light to medium. It is easy on the palate, with no lingering finish.

- Castellana (veraison): Medium fruity green olive, with hints of grass, banana and green almond, evolving to aromatic and herbaceous plants. In the mouth, it presents a slight bitterness and evolving pungency, which reaches a medium-high level, with an aftertaste of dried fruits and a lingering finish due to the degree of pungency.

- Castellana (ripe): Medium-low fruity ripe, green olive, with aromas of olive leaf, tomato, green vegetables, dried fruits and a hay base. In the mouth, it is first sweet, then slightly bitter, evolving to pungent, with a dried fruit finish in the mouth and a base of ripe fruits.

- Gordera (veraison): Medium green olive fruity, with notes of grass, artichoke and green banana, evolving to ripe fruits, vanilla and fennel. In the mouth, it is sweet, with low bitterness and a slight pungency, leaving an aftertaste of green vegetables and dried fruits.

- Gordera (ripe): Light ripe olive fruit, with a base of fruit and overripe vegetables, which give it sour notes, recalling olives in brine and withered flowers. In the mouth, it is sweet, with only a slight bitterness and pungency, with an aftertaste of overripe olives and stale dried fruits.

- Manzanilla (veraison): Medium-light green olive with ripe olive notes, evolving to notes of grass, banana, green almond and tomato plant, with a base of tea and bay leaf. In the mouth, it highlights the characteristics noted in the nose, with a slight bitterness and medium-high pungency, leaving an aftertaste of ripe fruit and dried fruits.

- Manzanilla (ripe): Medium ripe olive fruity, with notes of apple and banana, tomato plant and vanilla, with a base of overripe olives and withering flowers. It is first sweet in the mouth, with a slight bitterness and medium pungency, leaving an aftertaste of dried fruits.

- Martin Galgo (veraison): Medium-light ripe green olive fruity, with a base of banana, wildflowers, fresh green vegetables and dried fruits. In the mouth, it is first mild, with an almost imperceptible bitterness and slight pungency that fast disappears: Slightly dense, it leaves an aftertaste of dried fruits.

- Martín Galgo (ripe): Light ripe olive fruity, with a base of cooked vegetables and overripe fruit, with a slight defect of sour fruit. Pasty in the mouth, with almost imperceptible bitterness and pungency, evolving to notes of dried fruit and an aftertaste of boiled vegetables.

\subsubsection{Stability Parameters}

Other important parameters to be evaluated in virgin olive oils are the stability parameters because they are related to the commercial quality of the oils that determine their shelf-life, which is the length of time for which the oil can be distributed in commercial outlets maintaining good sensory characteristics [14]. 
The oxidative stability of an oil measures its resistance to rancidification. This process consists of a consecutive series of fatty acid oxidation reactions that begin when there is a double bond. Hence the oxidative stability greatly depends on the fatty acid profile of oils, generally being lower, when the oil has a lower percentage of unsaturated or polyunsaturated fatty acids. However, this value depends also on the content of natural antioxidants, among which the most important are phenols and tocopherols, which can delay the reactions that generate the rancidification of the oils, leading to a longer useful life.

The maturity of olives can affect the stability of the oils, as it can generate changes in certain compounds with antioxidative activity. However, there is some controversy regarding these changes. For example, in the case of total phenol content, some studies suggest that their content increases with ripening [7], while others report that these compounds decrease during the harvest period [32]. These contradictions may be related to the different varieties analysed [8], although a larger number of studies conclude that total phenol content declines with olive maturity $[6,8,27,33,34]$.

In the case of the virgin olive oils produced with olives of the Castellana variety, which is predominant in the PDO, a decrease in total phenol content was found as olive maturity increased (Figure 1), although these changes were not statistically significant. Generally, none of the varieties shows significant differences as regards the content in phenolic compounds between the oils elaborated with veraison and mature olives, with the varietal component being more important.

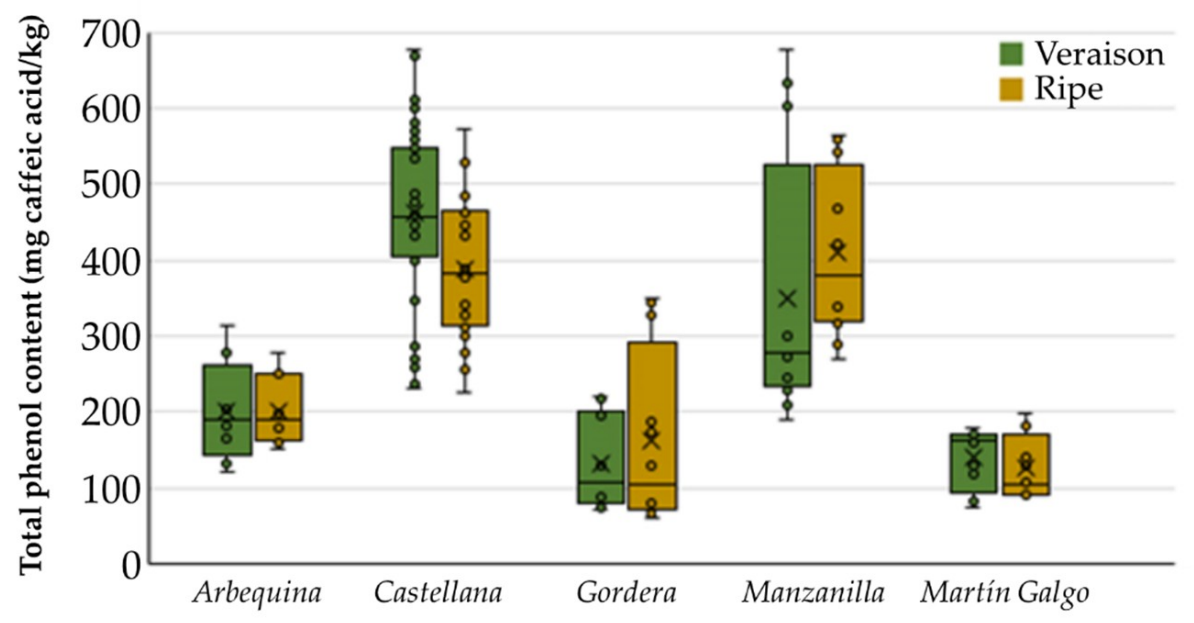

Figure 1. Total phenol content (mg caffeic acid $/ \mathrm{kg}$ ) for the virgin olive oils produced with the varieties of olives cultivated in the Aceite de la Alcarria PDO (veraison and ripe). The whisker ends show the maximum and minimum values, while the $X$ represents the mean values of the oils elaborated across the four consecutive olive crop seasons under study.

The virgin olive oils with the highest content in total phenol content are those produced with Castellana olives in veraison, which yielded values of up to $677.8 \mathrm{mg} / \mathrm{kg}$, and a mean value across the samples, over the four consecutive seasons, of $462.5 \mathrm{mg} / \mathrm{kg}$. The highest value of the virgin oils elaborated with veraison Manzanilla olives is similar $(677.2 \mathrm{mg} / \mathrm{kg})$, although greater variability was found in this variety, presenting a lower mean value $(349.8 \mathrm{mg} / \mathrm{kg})$. In contrast, the virgin oils with the lowest total phenol content were those made with olives of the Martin Galgo variety, in more advanced stages of maturity, with a mean value of $126.0 \mathrm{mg} / \mathrm{kg}$ (Figure 1 ).

The tocopherol content exhibits a similar pattern although the differences between the oils produced with veraison and mature olives are smaller. Generally, there is a decrease in tocopherol content in the oils made with mature olives, primarily in the case of the Castellana variety, although this difference is not statistically significant. Tocopherols are essential compounds in the sense that the human body is unable to synthesise them, and thus must be incorporated into our organism through diet [35]. 
These small variations in the antioxidant compounds are also reflected in a decrease in the oxidative stability of the oils produced with mature olives, being especially noticeable in the Castellana oils (Figure 2). Given that this variety is predominant and representative of the Aceite de la Alcarria PDO, it would be recommendable to elaborate oil with olives in an early stage of ripening, given their antioxidant capacity, which would yield positive effects on health and greater stability.

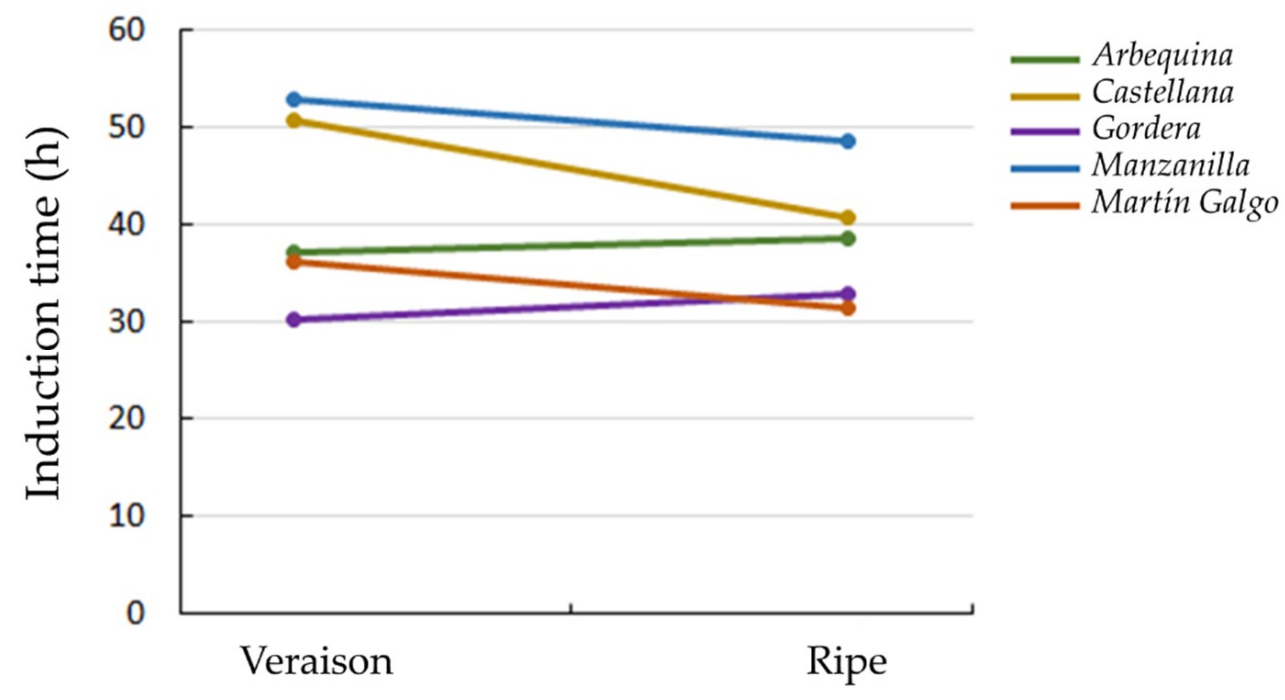

Figure 2. Evolution of the oxidative stability for the virgin olive oils produced with the varieties of olives cultivated in the Aceite de la Alcarria PDO (veraison and ripe). Mean values for the samples collected across the four consecutive olive crop seasons under study.

The varieties that generate the least stable oils are Gordera and Martin Galgo, regardless of the state of maturity of the olives (Figure 2).

\subsubsection{Fatty Acid Composition}

Fatty acids are the main components of oils, and thus tend to establish their physical behaviour, greatly affecting their viscosity and determining their fusion point. Additionally, the chemical and nutritional properties of olive oil are notably influenced by these compounds.

However, the fatty acid composition has a relatively broad range of values in virgin olive oils due to the genetic and environmental factors which prevail during the fruit development, as well as the ripening stage of the olives at harvest time [36]. A number of authors have used fatty acid composition as a parameter for olive oil classification [14-17,31,37].

The ripening stage of the olives can have certain effects on fatty acids in oils. Previous studies have shown that olive oils elaborated with olives in an advanced state of maturity present lower palmitic acid content, the main saturated fatty acid, and in oleic acid, the main monounsaturated fatty acid. In contrast, such oils present higher linoleic acid content [8]. Small changes can be observed in the virgin olive oils produced with olives grown in the Aceite de la Alcarria PDO (Table 3), with this being general across all the varieties, although the differences were not statistically significant. 
Table 3. Variation in the proportion of palmitic acid, oleic acid and linoleic acid, according to olive maturity, for the virgin olive oils produced with the variety of olives grown in the Aceite de la Alcarria $P D O$ (veraison and ripe). The data show the mean values and the standard deviations for the samples collected across the four consecutive olive crop seasons under study.

\begin{tabular}{ccccc}
\hline & & Palmitic Acid (\%) & Oleic Acid (\%) & Linoleic Acid (\%) \\
\hline \multirow{2}{*}{ Arbequina } & Veraison & $12.37 \pm 1.58$ & $75.31 \pm 3.25$ & $7.62 \pm 1.34$ \\
& Ripe & $12.53 \pm 1.16$ & $74.95 \pm 2.50$ & $7.59 \pm 1.16$ \\
\hline \multirow{2}{*}{ Castellana } & Veraison & $14.27 \pm 1.71$ & $75.25 \pm 2.13$ & $5.03 \pm 0.98$ \\
& Ripe & $13.81 \pm 0.88$ & $74.21 \pm 2.05$ & $5.98 \pm 0.92$ \\
\hline \multirow{2}{*}{ Gordera } & Veraison & $12.00 \pm 0.99$ & $77.38 \pm 1.71$ & $5.42 \pm 1.02$ \\
& Ripe & $11.96 \pm 0.93$ & $75.74 \pm 2.74$ & $6.95 \pm 1.94$ \\
\hline \multirow{2}{*}{ Manzanilla } & Veraison & $12.26 \pm 1.99$ & $78.17 \pm 4.48$ & $4.17 \pm 1.31$ \\
& Ripe & $11.89 \pm 1.17$ & $78.00 \pm 2.48$ & $4.74 \pm 0.43$ \\
\hline \multirow{2}{*}{ Martin Galgo } & Veraison & $11.25 \pm 0.99$ & $78.46 \pm 2.65$ & $5.15 \pm 1.38$ \\
& Ripe & $11.14 \pm 0.96$ & $77.28 \pm 3.41$ & $4.88 \pm 2.68$ \\
\hline
\end{tabular}

No significant differences were found between maturation stages (Duncan test, $p<0.05$ ).

Generally, the amounts of oleic and linoleic acids are inversely proportional in olive oils, such that when the content of one increases, that of the other decreases. During ripening, this is the result of the activity of the oleate desaturase enzyme, which transforms oleic acid into linoleic acid during triglyceride biosynthesis [6]. The presence of a greater proportion of linoleic acid, which has a higher degree of unsaturation, which can be beneficial for the nutritional value of the olive oil.

The different fatty acid content values in all the analysed samples fall within the ranges provided for in Commission Regulation (EC) No 1989/2003, that consider the following values: myristic $\leq 0.05 \%$; palmitic $=7.5-20.0 \%$; palmitoleic $=0.3-3.5 \%$; arachidic $\leq 0.6 \%$; behenic $\leq 0.2 \%$; stearic $=0.5-5.0 \%$; oleic $=55.0-83.0 \%$; linoleic $=3.5-21 \%$; linolenic $\leq 1.0 \%[38]$.

\subsubsection{Sterols and Triterpenic Dialcohols Composition}

Sterols are monovalent higher alcohols that are part of the unsaponifiable fraction of olive oil. The composition of the sterolic fraction of olive oil is used for detecting adulterations with other vegetable oils and can be considered as the fingerprint of oils [39-41]. In addition, the use of sterols and triterpenic dialcohol profiles has been proposed to classify virgin olive oils according to their variety [42-44].

Other constituents of the unsaponifiable fraction are triterpenic dialcohols (erythrodiol + uvaol), which levels in olive oil are generally low as they are mainly found in the olive skin [42]. In contrast, in olive-pomace oil, as organic solvents (hexane) are used in the extraction process, the levels are higher. Thus, the content of triterpenic dialcohols is limited by Regulation EEC 2568/91 to a maximum of $4.5 \%$ of the total sterols [19], because higher concentrations are indicative for possible adulteration with pomace oil, and therefore may act as another important index of virgin olive oil authenticity [45].

In all the samples analysed, the levels of sterols and triterpenic dialcohols content were found to be within the intervals required by Commission Regulation (EC) No. 1989/2003 for extra virgin olive oils (cholesterol $\leq 0.5 \%$; campesterol $\leq 4.0 \%$; stigmasterol $<$ campesterol; $\beta$-apparent sitosterol $\geq 93.0 \% ; \Delta$-7-stigmasterol $\leq 0.5 \%$; total sterols $\geq 1000 \mathrm{mg} / \mathrm{kg}$; erythrodiol + uvaol $\leq 4.5 \%$ ) [38], with the exception of total sterol content. With regard to this latter parameter, the oils made with Castellana and Gordera olives presented values below $1.000 \mathrm{mg} / \mathrm{kg}$, which does not make it a fraudulent oil, as this seems to be an intrinsic characteristic of these varieties. The same result was also found in some of the Martin Galgo samples (Figure 3). 


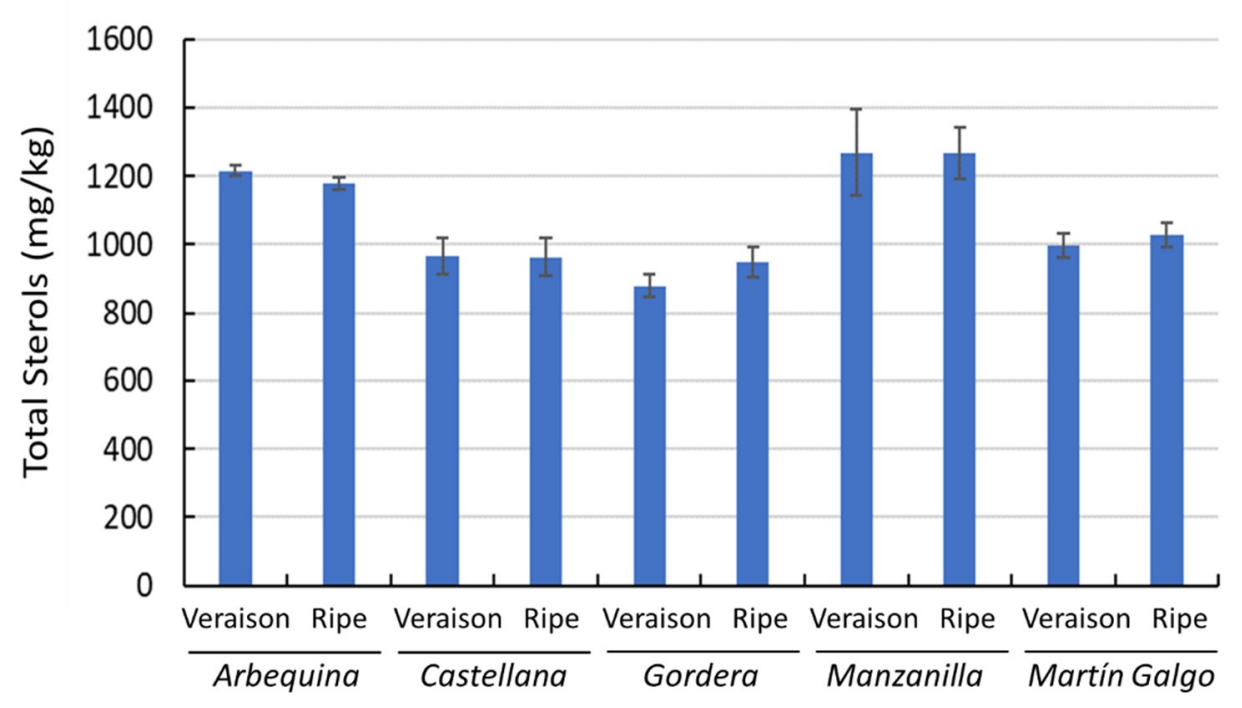

Figure 3. Total sterol content $(\mathrm{mg} / \mathrm{kg}$ ) the monovarietal oils produced with the varieties of olives grown in the Aceite de la Alcarria PDO (veraison and ripe). Mean values for the samples collected across the four consecutive olive crop seasons under study. No significant differences were found between maturation stages (Duncan test, $p<0.05$ ).

The state of ripening of the olives did not significantly affect the sterol and triterpenic dialcohol content in any of the varieties under study, which contrasts with the findings of the studies by Fuentes et al. [46] on oils produced in Extremadura, using olives indigenous to the autonomous community, where the content in total sterols, apparent $\beta$-sitosterol and erythrodiol + uvaol was found to decrease as olives ripened.

3.2. Characterization of Monovarietal Virgin Olive Oils from Aceite de la Alcarria PDO According to Olive Crop Season

Agro-climatic conditions, such as the planting pattern, light interception and the amount of water available, may be another factor with an impact on the physicochemical parameters of olive oil [11,12]. Thus, to characterise monovarietal virgin olive oils produced with olives grown in the Aceite de la Alcarria PDO, it is also important to evaluate possible changes in their physicochemical composition that might be affected by the climatic conditions prevalent in the different olive crop seasons under study.

An analysis of the four seasons considered in this study reveals small differences in the physicochemical composition of the oils, which tend to present similar tendencies in relation to the season analysed. The olive oil samples that showed the greatest differences were those from the $2017 / 2018$ season, in which all the varieties yielded different virgin olive oils, while the differences in the other seasons were less clear, with some overlapping appreciated.

The main difference can be seen in the composition of oleic acid and linoleic acid. In this case, the largest changes correspond to the 2017/2018 season, which showed the lowest values for the former and highest for the latter (Figure 4). This trend was similar for all the five olive varieties under study. The lowest linoleic acid content and the highest oleic acid content correspond to the 2018/2019 season, in which all the varieties presented lower levels of linoleic acid and higher levels of oleic acid. 


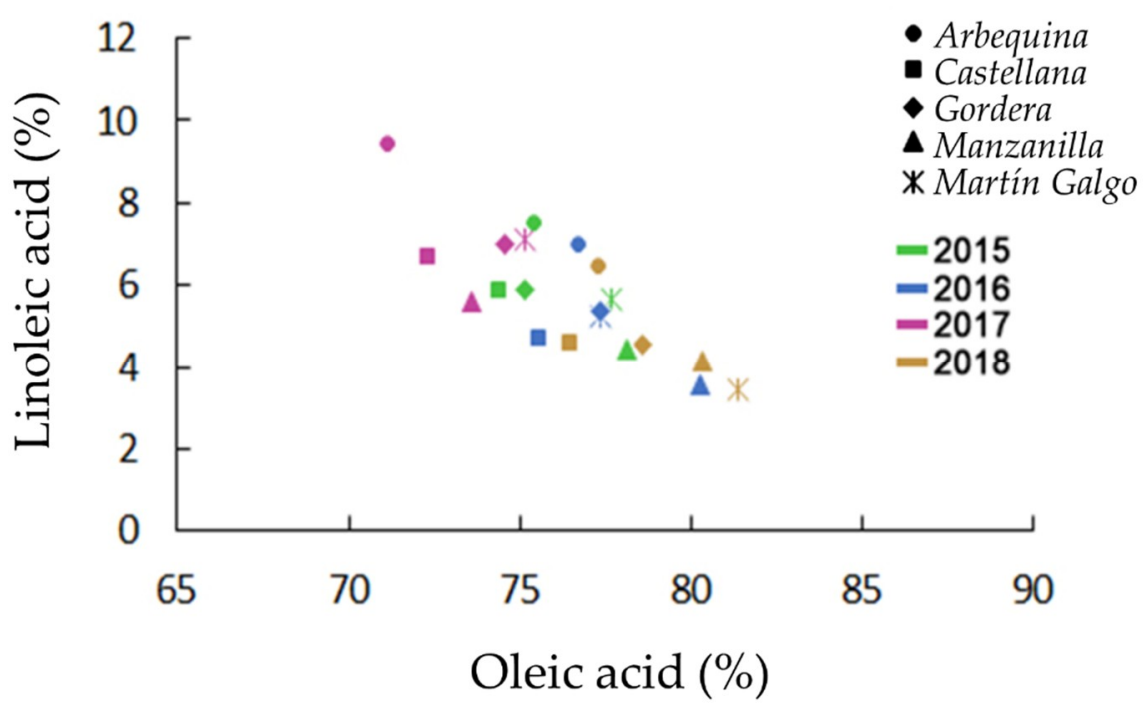

Figure 4. Oleic and linoleic acid content of the monovarietal oils produced with the varieties of olives grown in the Aceite de la Alcarria PDO across four consecutive olive crop seasons. Mean values of the samples elaborated in each season.

Previous studies have reported the impact of rainfall on the most common fatty acids, such that in drier years there is a decrease in oleic acid and an increase in linoleic and palmitic acids [13]. This same effect is found when olives are submitted to water stress treatments [47], especially in the case of high-intensive crops, in which the intention is to maximise production [48].

In the case of other compounds that might be affected by climatic conditions, this tendency is less clear. For example, the total sterol content has also been shown to be impacted by the amount of precipitation, although this association is less robust and varies according to an olive variety $[13,49]$. Among the sterols, campesterol, whose content appears not to decline in dry, hot climates [13], shows no clear tendency in relation to the season in which the olives were harvested in our study (Figure 5).

$2015 \square 2016 \square 2017 \square 2018$

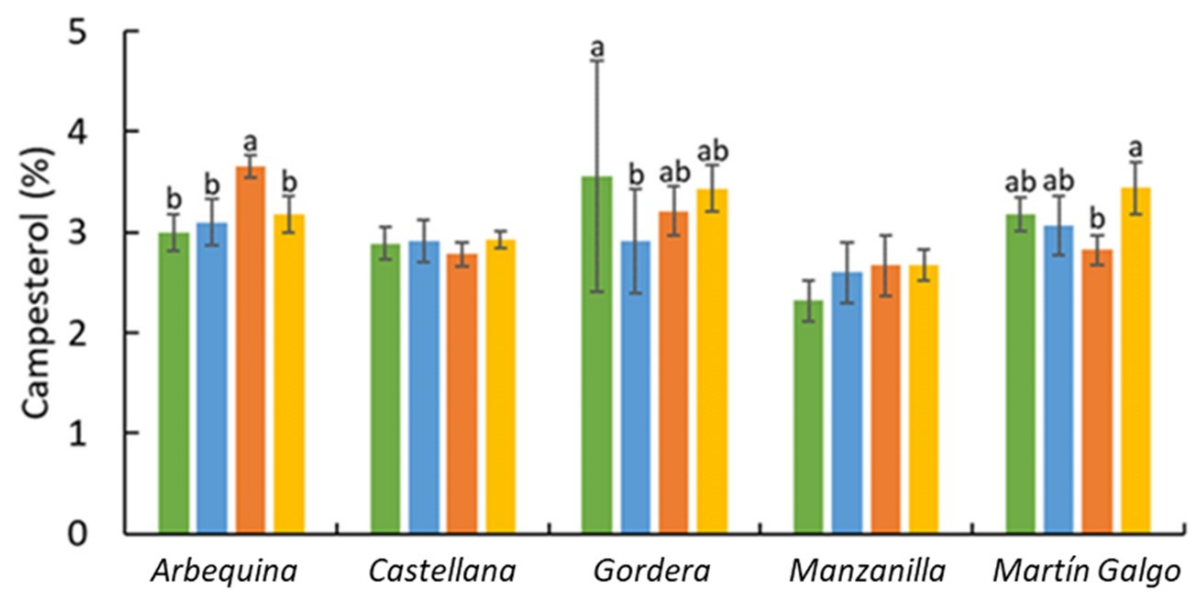

Figure 5. Campesterol content of the monovarietal oils produced with the varieties of olives grown in the Aceite de la Alcarria PDO during the four consecutive olive crop seasons under study. Mean values of the samples elaborated in each season. Different letters within each variety indicate significant differences among seasons (Duncan test, $p<0.05$ ). 
The oils made using Manzanilla and Castellana olives showed no significant differences, while the Arbequina, Gordera and Martin Galgo varieties presented their highest campesterol values in different seasons.

As regards the phenol compounds, the monovarietal olive oils showed differences according to the olive variety studied (Figure 6), despite maintaining their varietal characteristics, with Castellana and Manzanilla varieties exhibiting the highest phenol compound content in the 4 seasons under study. Studies on olives submitted to different irrigation treatments tend to report that the phenol compound content increases when the amounts of water applied are lower [50], with this effect significantly increasing when the water stress is early [51,52]. This moment tends to coincide with the summer when rainfall can be variable across the sampling seasons analysed. Hence, the impact on phenol compound content may stem more from rainfall at certain moments of fruit development, rather than from the total amount of rainfall over the year. This would make it more difficult to find similar patterns in phenol compound content across all the varieties and sampling, as the provision of water available for the olive trees cannot be controlled.

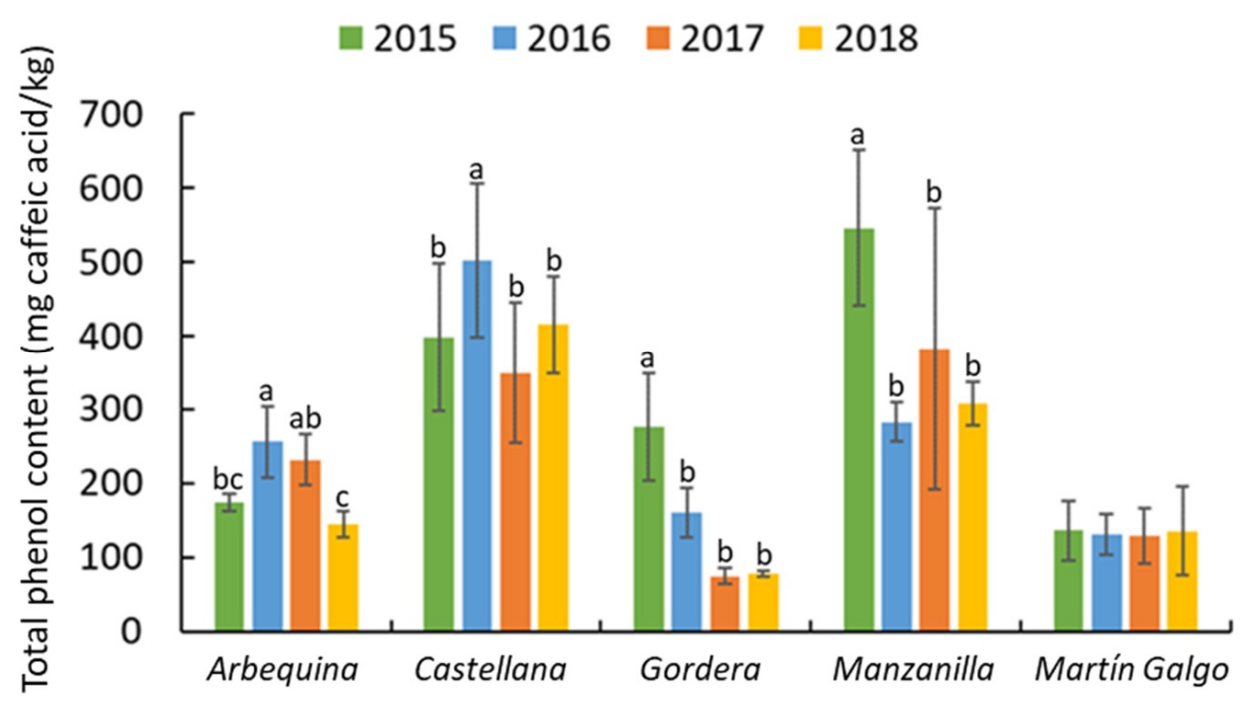

Figure 6. Total phenol content of the monovarietal oils produced with the varieties of olives grown in the Aceite de la Alcarria PDO during the four consecutive olive crop seasons under study. Mean values of the samples elaborated in each season. Different letters within each variety indicate significant differences among seasons (Duncan test, $p<0.05$ ).

The oxidative stability values for the virgin olive oils show the impact of fatty acid content. The greater proportion of linoleic acid in the $2017 / 2018$ season is reflected in the lower levels of oxidative stability in the same oils (Figure 7), although in most varieties the differences with other seasons are non-significant. This is because oxidative stability can also be affected by other compounds, such as tocopherols and phenols, which showed no clear trend across the four seasons under study. In any event, the monovarietal virgin olive oils elaborated with olives from the Aceite de la Alcarria PDO typically maintain their varietal characteristics, with the greatest stability in the four study seasons corresponding to the virgin olive oils made with olives of the Castellana and Manzanilla varieties.

In sum, it can be concluded that agroclimatic conditions affect the physicochemical composition of the oils, although these changes tend not to be significant, with varietal characteristics being maintained regardless of the harvesting season analysed. 


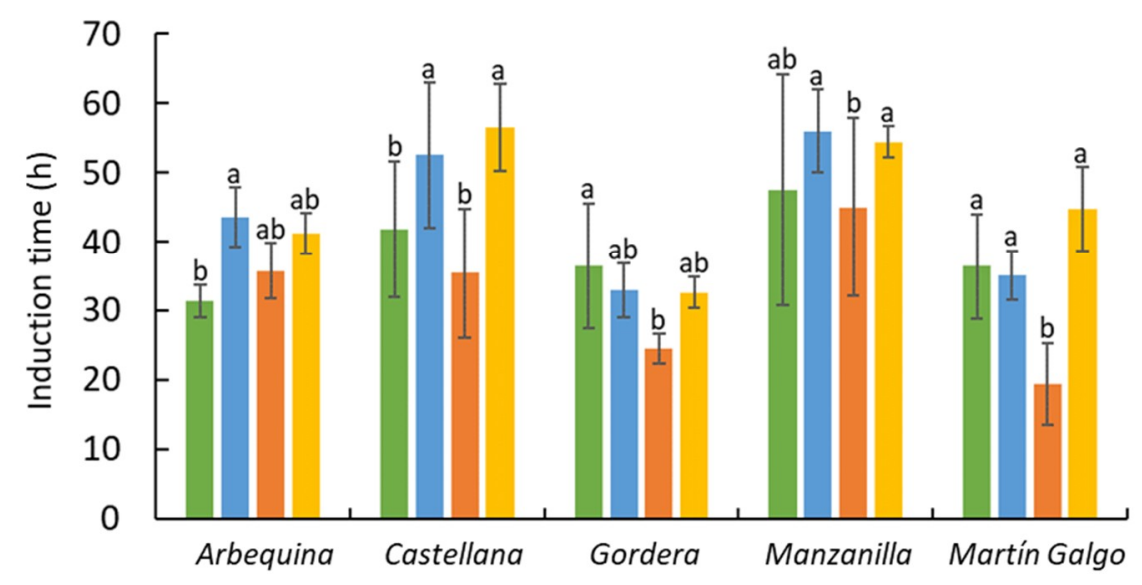

Figure 7. Oxidative stability of the monovarietal oils produced with the varieties of olives grown in the Aceite de la Alcarria PDO during the four consecutive olive crop seasons under study. Mean values of the samples elaborated in each season. Different letters within each variety indicate significant differences among seasons (Duncan test, $p<0.05$ ).

\subsection{Physicochemical and Sensory Characterization of the Virgin Olive Oils the Mills Registered under the Aceite de la Alcarria PDO}

All the virgin olive oils analysed in this study presented low values on the regulated physicochemical quality parameters considered, with all of them being classified as "extra virgin". These values confirm the physicochemical quality of the virgin olive oils produced in the study area.

As regards the regulated organoleptic quality parameters, $62.5 \%$ of the samples analysed were classified as "extra virgin", since the sensory evaluation determined that the mean of defects was 0 and the mean of the fruity attribute was above 0 . The remaining $37.5 \%$ of the oil samples were listed as "virgin" because the mean of defects was between 0 and 3.5. All the olive oils samples classified as "virgin" were collected from end-of-season deposits, which corroborates the loss of quality in oils made from Castellana olives as the harvesting season progresses. This leads us to recommend early harvesting to producers in the area. The sensory defect found in the virgin olive oil samples was again the winey attribute.

The oils collected from the storage tanks at the oil mills showed similar characteristics to those monovarietal oils from Castellana, since this is the predominant variety in the area. Thus, oxidative stability showed medium values, but always higher when the samples were collected from deposits where the oil was elaborated from olives collected at the beginning of the season. This medium-level stability may be associated with the medium content of total phenols. The highest values found for oxidative stability was achieved by the oils produced in the Valdeolivas mill (Cuenca). However, these values were still far from those corresponding to varieties known to be highly stable such as Picual and Cornicabra, both predominant in other nearby olive-growing areas [14-16]. The values obtained guarantee the virgin olive oils from the study area have a considerable commercial value.

The fatty acid composition of the olive oils also showed similar values to those observed for the monovarietal Castellana oil. The oils from the study area are distinguished by their high palmitic and palmitoleic acid content, their low oleic acid content, and their medium values in stearic and linoleic acids, compared to the other varieties in the study area.

The sterol composition of the virgin olive oils presents, as in the case of the fatty acid content, similar values to those observed for the Castellana variety in the study on the monovarietal virgin olive oils: high campesterol values, near the values established by 
regulations, but much lower than those found in other varieties such as Cornicabra [14,15], and low values of total sterols and high values of erythrodiol + uvaol.

\section{Conclusions}

Olive ripeness impacts the characteristics of the monovarietal virgin olive oils produced from the olive varieties grown in La Alcarria as olive oils made from olives in veraison showed better values regarding quality regulated parameters. However, all the monovarietal virgin olive oils were classified as extra virgin olive oil regardless of variety or maturation stage. In addition, fruitiness declines as ripening progresses, although this was only significant in the varieties of Castellana, Gordera and Manzanilla. Small variations in antioxidant compounds are reflected in the decreased oxidative stability of the oils produced with ripe olives.

It has also been observed that agroclimatic conditions affect the physicochemical composition of oils, although such changes tend not to be significant, with the characteristics of the variety being maintained, regardless of the season analysed.

Finally, the physicochemical and sensory analyses of the virgin olive oils produced in the mills listed under the Aceite de la Alcarria PDO, presented, as might be expected, similar values to those found in the monovarietal virgin olive oils made with Castellana olives, which are clearly predominant in the study area.

The characterization of monovarietal olive oils allows finding differences in terms of the physicochemical composition and sensory parameters of olive oils. For this reason, it is interesting to delve into the study of local varieties that can provide greater variability in terms of the sensory notes of extra virgin olive oil, to satisfy the taste of all consumers.

Author Contributions: Conceptualization, J.E.P.; methodology, J.T., M.S., A.R. and D.C.Z.; validation, D.C.Z. and J.E.P.; formal analysis, A.R. and D.C.Z.; investigation, J.E.P. and M.Á.-O.; resources, J.E.P., J.T., M.S. and D.C.Z.; data curation, A.R.; writing-original draft preparation, J.E.P. and M.Á.-O.; writing—review and editing, A.R. and M.Á.-O.; supervision, J.E.P.; project administration, J.E.P.; funding acquisition, J.E.P. All authors have read and agreed to the published version of the manuscript.

Funding: This research received no external funding.

Acknowledgments: In addition, the authors want to acknowledge olive oil mills Aceites Delgado, S.L., SAT Alcarria Baja and Sociedad Cooperativa Alta Alcarria for their collaboration and for providing oil samples for analysis.

Conflicts of Interest: The authors declare no conflict of interest.

\section{References}

1. Consejo de la Unión Europea. Del Reglamento (CE) no 510/2006 del Consejo sobre la protección de las indicaciones geográficas y de las denominaciones de origen de los productos agrícolas y alimenticios. Diario Of. Unión Eur. 2006, 93, 39-41.

2. Zafra, A.; Mayordomo, M.C.; Garrido, J.M.; Torres, M.A. Variedades de Olivo de los Municipios de la Alcarria Conquense; Ministerio de Medio Ambiente y Medio Rural y Marino: Jaén, Spain, 2011; pp. 1-43.

3. Díaz-Díaz, S.; Sena-Moreno, E.; Álvarez-Ortí, M.; Pardo, J.E.; Suárez, M.; Rabadán, A. Characterisation of virgin olive oils from variety Benizal (Albacete, Spain). Riv. Ital. Delle Sostanze Grasse 2018, 95, 249-254.

4. Fernandes, G.D.; Ellis, A.C.; Gámbaro, A.; Barrera-Arellano, D. Sensory evaluation of high-quality virigin olive oil: Panel analysis versus consumer perception. Curr. Opin. Food Sci. 2018, 21, 66-71. [CrossRef]

5. Zago, L.; Squeo, G.; Bertoncini, E.L.; Difonzo, G.; Caponio, F. Chemical and sensory characterization of Brazilian virgin olive oils. Food Res. Int. 2019, 126, 108588. [CrossRef]

6. Bakhouche, A.; Lozano-Sánchez, J.; Bengana, M.; Fernández-Gutiérrez, A.; Segura-Carretero, A. Time course of Algerian Azeradj extra-virgin olive oil quality during olive ripening. Eur. J. Lipid Sci. Technol. 2015, 117, 389-397. [CrossRef]

7. Gougoulias, N.; Giurgiulescu, L.; Vagelas, I.; Wogiatzi, E.; Ntalla, M.N. Changes in total phenol content and antioxidant activity of Greek table olive cultivar amfissis during maturation. Stud. Univ. Babes-Bolyai Chem. 2017, 62, 387-396. [CrossRef]

8. Navajas-Porras, B.; Pérez-Burillo, S.; Morales-Pérez, J.; Rufián-Henares, J.A.; Pastoriza, S. Relationship of quality parameters, antioxidant capacity and total phenolic content of EVOO with ripening state and olive variety. Food Chem. 2020, 325, 126926. [CrossRef] 
9. Peyrot des Gachons, C.; O'Keefe, A.J.; Slade, L.; Beauchamp, G.K. Protein suppresses both bitterness and oleocanthal-elicited pungency of extra virgin olive oil. Sci. Rep. 2021, 11, 11851. [CrossRef]

10. Andrewes, P.; Busch, J.L.H.C.; De Joode, T.; Groenewegen, A.; Alexandre, H. Sensory properties of virgin olive oil polyphenols: Identifcation of deacetoxy-ligstroside aglycon as a key contributor to pungency. J. Agric. Food Chem. 2003, 51, 1415-1420. [CrossRef] [PubMed]

11. Caruso, G.; Gucci, R.; Sifola, M.I.; Selvaggini, R.; Urbani, S.; Esposto, S.; Taticchi, A.; Servili, M. Irrigation and fruit canopy position modify oil quality of olive trees (cv. Frantoio). J. Sci. Food Agric. 2017, 97, 3530-3539. [CrossRef] [PubMed]

12. Rodrigues, N.; Casal, S.; Peres, A.M.; Baptista, P.; Pereira, J.A. Seeking for sensory differentiated olive oils? The urge to preserve old autochthonous olive cultivars. Food Res. Int. 2020, 128, 108759. [CrossRef]

13. Li, X.; Flynn, J.D.; Wang, S.C. The effects of variety, growing region, and drought stress on fatty acid and sterol compositions of California olive oil. J. Am. Oil Chem. Soc. 2019, 96, 215-230. [CrossRef]

14. Pardo, J.E.; Cuesta, M.A.; Alvarruiz, A. Evaluation of potential and real quality of virgin olive oil from the Designation of Origin Aceite Campo de Montiel (Ciudad Real, Spain). Food Chem. 2007, 100, 977-984. [CrossRef]

15. Pardo, J.E.; Cuesta, M.A.; Alvarruiz, A.; Granell, J.D.; Álvarez-Ortí, M. Evaluation of potencial and real qualities of virgin olive oil from the designation of origin (DO) "Aceite Montes de Alcaraz" (Albacete, Spain). Food Chem. 2011, 124, 1684-1690. [CrossRef]

16. Pardo, J.E.; Sena, E.; Cuesta, M.A.; Granell, J.D.; Valiente, J.; Álvarez-Ortí, M. Evaluation of potential and real quality of virgin olive oil from "Campos de Hellín" (Albacete, Spain). J. Am. Oil Chem. Soc. 2013, 90, 851-862. [CrossRef]

17. Pardo, J.E.; Tello, J.; Suárez, M.; Rabadán, A.; De Miguel, C.; Álvarez-Ortí, M. Variety characterization and influence of olive maturity in virgin olive oils from the area assigned to the Protected Designation of Origin "Aceite de la Alcarria" (Spain). Agronomy 2020, 10, 38. [CrossRef]

18. Uceda, M.; Frias, L. Harvest dates: Evolution of the fruit oil content, oil composition and oil quality. Proc. Segundo Semin. Oleic. Int. Cordoba Spain 1975, 6, 125-128.

19. EEC. Commision Regulation (EEC) No 2568/91 of 11 July 1991 on the characteristics of olive oil and olive-residue oil and on the relevant methods of analysis. Off. J. Eur. Union 1991, L248, 1.

20. EC. Commission Regulation (EC) No 796/2002 of 6 May 2002 amending Regulation (EEC) No 2568/91 on the characteristics of olive oil and olive-pomace oil and on the relevant methods of analysis and the additional notes in the Annex to Council Regulation (EEC) No 2658/87 on the tariff and statistical nomenclature and on the Common Customs Tariff. Off. J. Eur. Union 2002, L128, 8 .

21. Gutfinger, T. Polyphenols in olive virgin oils. J. Am. Oil Chem. Soc. 1981, 58, 966-968. [CrossRef]

22. AOCS. Determination of Tocopherols and Tocotrienols in Vegetable Oils and Fats by HPLC; AOCS: Champaign, IL, USA, 1989.

23. Gutiérrez, F. Determinación de la estabilidad oxidativa de aceites de oliva vírgenes: Comparación entre el método A.O.M. y el método Rancimat. Grasas Aceites 1989, 40, 1-5.

24. EEC. Commission Regulation (EEC) No 1429/92 of 26 May 1992 amending Regulation (EEC) No 2568/91 on the characteristics of olive oil and olive-residue oil and on the relevant methods of analysis. Off. J. Eur. Union 1992, L150, 17-20.

25. Rabadán, A.; Nunes, M.A.; Bessada, S.M.F.; Pardo, J.E.; Oliveira, M.B.P.P.; Álvarez-Ortí, M. From By-Product to the Food Chain: Melon (Cucumis melo L.) Seeds as Potential Source for Oils. Foods 2020, 9, 1341. [CrossRef]

26. Pardo, J.E.; Tardáguila, J.; Gómez, R. Control de Calidad en el Aceite de Oliva Virgen. In Servicio de Publicaciones del Campus de Albacete; Universidad de Castilla-La Mancha: Albacete, Spain, 1996.

27. Franco, M.N.; Sánchez, J.; de Miguel, C.; Martínez, M.; Martín-Vertedor, D. Influence of the fruit's ripeness on virgin olive oil quality. J. Oleo Sci. 2015, 64, 263-273. [CrossRef]

28. EC. Commission Regulation (EC) N $640 / 2008$ of of 4 July 2008 amending Regulation (EEC) No $2568 / 91$ on the characteristics of olive oil and olive-residue oil and on the relevant methods of análisis. Off. J. Eur. Union 2008, L178, 11.

29. IOC. Valoración Organoléptica del Aceite de Olive Virgen; IOC: Madrid, Spain, 2007; pp. 1-15.

30. SiAR. Sistema de Información Agroclimática para el Regadío. Ministerio de Agricultura, Pesca y Alimentación; Gobierno de España: Madrid, Spain, 2020.

31. Lukić, I.; Žanetić, M.; Jukić Špika, M.; Lukić, M.; Koprivnjak, O.; Brkić Bubola, K. Complex interactive effects of ripening degree, malaxation duration and temperature on Oblica cv. virgin olive oil phenols, volatiles and sensory quality. Food Chem. 2017, 232, 610-620. [CrossRef] [PubMed]

32. Deiana, P.; Santona, M.; Dettori, S.; Culeddu, N.; Dore, A.; Molinu, M.G. Multivariate approach to assess the chemical composition of Italian virgin olive oils as a function of variety and harvest period. Food Chem. 2019, 300, 125243. [CrossRef] [PubMed]

33. Nsir, H.; Taamalli, A.; Valli, E.; Bendini, A.; Toschi, T.G.; Zarrouk, M. Chemical composition and sensory quality of Tunisian "Sayali" virgin olive oils as affected by fruit ripening: Toward an appropriate harvesting time. J. Am. Oil Chem. Soc. 2017, 94, 913-922. [CrossRef]

34. Sicari, V. Antioxidant potential of extra virgin olive oils extracted from three different varieties cultivated in the Italian province of Reggio Calabria. J. App. Bot. Food Qual. 2017, 90, 76-82.

35. Sayago, A.; Marín, M.I.; Aparicio, R.; Morales, M.T. Vitamina E y aceites vegetales. Grasas Aceites 2007, 58 , 74-86.

36. Kiritsakis, A.; Markakis, P. Olive oil: A review. Adv. Food Res. 1987, 31, 453-482. [PubMed]

37. Martínez, M.; Fuentes, M.; Franco, M.N.; Sánchez, J.; de Miguel, C. Fatty acid profiles of virgin olive oils from the five olives growing zones of Extremadura (Spain). J. Am. Oil Chem. Soc. 2014, 91, 1921-1929. [CrossRef] 
38. EC. Commission Regulation (EC) No 1989/2003 of 6 November 2003 amending Regulation (EEC) No 2568/91 on the characteristics of olive oil and olive-pomace oil and on the relevant methods of analysis. Off. J. Eur. Union 2003, L295, 57-66.

39. Galeano, T.; Duran, I.; Sanchez, J.; Alexandre, M.F. Characterization of virgin olive oil according to its triglycerides and sterols composition by chemometric methods. Food Control 2005, 16, 339-347. [CrossRef]

40. Al-Ismail, K.M.; Alsaed, A.K.; Ahmad, R. Detection of olive oil adulteration with some plant oils by GLC analysis of sterols using polar column. Food Chem. 2010, 121, 1255-1259. [CrossRef]

41. Aparicio, R.; Morales, M.T.; Aparicio-Ruiz, R.; Tena, N.; Garcia-Gonzalez, D.L. Authenticity of olive oil: Mapping and comparing oficial methods and promising alternatives. Food Res. Int. 2013, 54, 2025-2038. [CrossRef]

42. Sánchez, J.; Osorio, E.; Montaño, A.M.; Martínez, M. Sterol and erythrodiol + uvaol content of virgin olive oils from cultivars of Extremadura (Spain). Food Chem. 2004, 87, 225-230. [CrossRef]

43. Matos, L.C.; Cunha, S.C.; Amaral, J.S.; Pereira, J.A.; Andrade, P.B.; Seabra, R.M.; Oliveira, B.P.P. Chemometric characterization of three varietal olive oils (Cvs. Cobrancosa, Madural and Verdeal Transmontana) extracted from olives with different maturation indices. Food Chem. 2007, 102, 406-414. [CrossRef]

44. Oueslati, I.; Anniva, C.; Daoud, D.; Tsimidou, M.Z.; Zarrouk, M. Virgin olive oil (VOO) production in Tunisia: The commercial potential of the major olive varieties from the arid Tataouine zone. Food Chem. 2009, 112, 733-741. [CrossRef]

45. Martinez, M.; de Miguel, C.; Fuentes, M.; Martin, F.; Sánchez, J. The sterol and erythrodiol + uvaol content of virgin olive oils produced in five olive-growing zones of Extremadura (Spain). J. Am. Oil Chem. Soc. 2015, 93, 227-235.

46. Fuentes, M.; De Miguel, C.; Marín, J.; Sánchez, J.; Martinez, M.; Martin, M.; Franco, M.N. Chemical composition of virgin olive oils according to the ripening in olives. Food Chem. 2013, 141, 2575-2581. [CrossRef] [PubMed]

47. Valenčič, V.; Podgornik, M.; Bandelj, D.; Bučar-Miklavčič, M.; Bečter, E.; Miklavčič Vičnjevec, A.; Pintar, M.; Baruca Arbeiter, A.; Hladnik, M.; Butinar, B. Influence of irrigation treatments on the yield and quality of "Istrska belica" olive oil. Acta Hortic. 2018, 1199, 471-476. [CrossRef]

48. García, J.M.; Hueso, A.; Gómez del Campo, M. Deficit irrigation during the oil synthesis period affects olive oil quality in high-density orchards (cv. Arbequina). Agric. Water Manag. 2020, 230, 105858. [CrossRef]

49. Berenguer, M.J.; Vossen, P.M.; Grattan, S.R.; Connell, J.H.; Polito, V.S. Tree irrigation levels for optimum chemical and sensory properties of olive oil. Hortscience 2006, 41, 427-432. [CrossRef]

50. Caruso, G.; Gucci, R.; Urbani, S.; Esposto, S.; Taticchi, A.; Di Maio, I.; Selvaggini, R.; Servili, M. Effect of different irrigation volumes during fruit development on quality of virgin olive oil of cv. Frantoio. Agric. Water Manag. 2014, 134, 94-103. [CrossRef]

51. Caruso, G.; Gennai, C.; Gucci, R.; Esposto, S.; Taticchi, A.; Urbani, S.; Servili, M. The effect of the timing of water deficit on yield components and oil quality of olive trees. Acta Hortic. 2017, 1150, 267-271. [CrossRef]

52. Gucci, R.; Caruso, G.; Gennai, C.; Esposto, S.; Urbani, S.; Servili, M. Fruit growth, yield and oil quality changes induced by deficit irrigation at different stages of olive fruit development. Agric. Water Manag. 2019, 212, 88-98. [CrossRef] 